АССЄВ М. А., провідний інженер (Харківське відділення філії «ПВІЗТ» ПАТ «Укрзалізниця»)

\title{
Розробка математичної моделі процесу обтікання вагонів повітряним потоком
}

Проаналізовано роботу підсистем автоматичного регулювання швидкості скочування відчепів в автоматизованих системах керування сортувальними станціями. Сформовано науковий підхід щзодо визначення потенціалу швидкості вітру при обтіканні вагонів для підвищення точності розрахунку швидкості виходу відчепів з паркової гальмової позицї. Запропонований підхід дає змогу враховувати змінне значення швидкості вітру, деформацію поля швидкості вітру при обтіканні рельєфу та вагонів на коліях сортувального парку.

Ключові слова: сортувальна гірка, деформаџія поля швидкості вітру, метеорологічні параметри, потенціал швидкості, відчеп.

\begin{abstract}
Постановка проблеми
Одним з основних напрямків Стратегії розвитку залізничного транспорту України є зниження витрат енергоресурсів. Покращення якості послуг та формування конкуренції на ринку залізничних перевезень - пріоритетні завдання залізничного транспорту.

Щорічно в Україні перевозиться залізничним транспортом більш ніж 430 млн. т вантажу за допомогою більш ніж 120 тис. вантажних вагонів, більшість 3 яких переробляється на сортувальних станціях. Процес розформування составів $є$ найбільш складним та енергоємним процесом на сортувальних станціях. Для зменшення експлуатаційних витрат, ефективного використання технологічного обладнання сортувальних станцій, покращення умов праці працівників станції і збільшення продуктивності роботи на вітчизняних та закордонних сортувальних станціях впроваджують комплексні системи автоматизованого керування сортувальними станціями [1].
\end{abstract}

Одним з головних завдань, які вирішуються в автоматизованих системах керування сортувальною станцією, є автоматизація регулювання швидкості скочування відчепів [2]. Максимальне заповнення колій сортувального парку вагонами та забезпечення безпечної швидкості зіткнення відчепів з відчепами, що розташовуються на коліях сортувального парку, два головних завдання у сортувальному процесі, за які і відповідає підсистема автоматичного регулювання швидкості скочування відчепів. Досвід роботи вітчизняних та закордонних автоматизованих сортувальних гірок показує, що за рахунок впровадження підсистеми автоматичного регулювання швидкості відчепів покращилась якість сортувального процесу, а саме: скоротились кількість та довжина

(C) M. A. Асєєв, 2017 вікон на коліях сортувального парку, зменшився обсяг маневрової роботи на станції, покращились умови праці робітників, підвищився рівень схоронності вагонів та вантажів [3].

Отже, для збереження енергетичних ресурсів та покращення якості сортувального процесу на залізничних станціях України актуальним є завдання вивчення досвіду експлуатації підсистем автоматичного регулювання швидкості скочування відчепів та удосконалення існуючих процедур розрахунку технологічних параметрів сортувальних гірок.

\begin{tabular}{c}
\hline Аналіз останніх досліджень і публікацій \\
Аналіз роботи підсистем автоматичного
\end{tabular} регулювання швидкості скочування відчепів у відомих автоматизованих системах виявив, що шляхом впровадження таких підсистем не в повній мірі можна забезпечити високу якість сортувального процесу (зменшити довжину вікон та забезпечити допустиму швидкість зіткнення вагонів) [4]. У процесі експлуатації вказаних підсистем виявлено окремі їх недоліки, а саме: недосконалі технологічні алгоритми, невеликий відсоток реалізації розрахункових швидкостей виходу 3 гальмових позицій, низький рівень урахування випадкових параметрів метеорологічних умов, неможливість достовірного визначення місцезнаходження відчепів у зоні дії пристроїв контролю зайнятості колій.

Уточнення параметрів метеорологічних умов та ходових властивостей відчепів - два головних способи підвищення точності розрахунку швидкості виходу відчепів з паркової гальмової позиції (ПГП).

При підвищенні точності розрахунку швидкості виходу відчепів з ПГП шляхом уточнення ходових властивостей відчепів як основний критерій оцінки якості прицільного гальмування прийнято середню величину вікна в сортувальному парку при фіксованому значенні імовірності перевищення 
нормативної швидкості співударяння відчепів. Авторами було порівняно якість прицільного регулювання швидкості за відсутності та наявності інформації про ходові характеристики одновагонного відчепа i відчепів 3 різною кількістю вагонів. Впровадження системи уточнення ходових характеристик одновагонного відчепа дає змогу суттєво покращити якість прицільного регулювання. Однак для відчепів 3 кількістю вагонів більше ніж п’ять використання вказаної системи не є доцільним [5].

У роботі [6] розроблено напрямок щодо підвищення точності розрахунку швидкості виходу відчепів 3 паркової гальмової позиції шляхом уточнення параметрів метеорологічних умов. 3 усіх наведених методів опису суцільного середовища доцільним $\epsilon$ використання способу Ейлера, а для знаходження потенціалу швидкості у будь-якій точці сортувального парку - рівняння Лапласа.

\section{Виділення невирішених раніше частин загальної} проблеми

На даний час в автоматизованих системах параметри метеорологічних умов визначаються за допомогою метеостанції (розташовується на території станції з флюгером на відстані 10-15 м від рівня землі) або двох метеорологічних датчиків (один розташовують на гірці, другий - біля першої гальмової позиції на рівні даху вагонів). Дані з метеостанції i датчиків надходять до головного сервера системи, після чого остання розраховує прискорення кожного відчепа. Дані з метеорологічних датчиків отримують у конкретній точці на конкретній відстані від землі. При цьому не враховується швидкість вітру, яка безпосередньо діє на відчеп, i ситуація на коліях сортувального парку.

\section{Формулювання цілей}

Метою роботи $є$ підвищення ефективності сортувального процесу шляхом формування математичної моделі процесу обтікання вагонів повітряним потоком i адаптації іiі в автоматичні системи регулювання швидкості скочування відчепів на підгіркових коліях. Для досягнення поставленої мети необхідно розв'язати задачу щодо розрахунку бокової сили вітру, що діє на вагони. При розрахунку цієї сили необхідно враховувати змінні значення швидкості вітру з висотою, рельєф сортувальної гірки, вплив вагонів на коліях сортувального парку на формування поля швидкості вітру біля них, деформацію поля швидкості вітру при обтіканні рельєфу сортувального парку і вагонів на підгіркових коліях.

\section{Виклад основного матеріалу дослідження}

Удосконалити метод розрахунку швидкості виходу відчепів з паркової гальмової позиції пропонується за рахунок уточнення параметрів метеорологічних умов. Головною задачею є розрахунок бокової сили, яка буде діяти на вагони (рис. 1), за умови їх обтікання повітряним потоком (рис. 2). Під впливом нерівності поверхні сортувального парку та місцезнаходження відчепів змінюється характер руху і турбулентний режим повітряних потоків, що призводить до істотної зміни розподілу поздовжнього профілю вітру [7]. Для розрахунку сили необхідно розв'язати гідродинамічну задачу та визначити поле швидкості повітряного потоку при обтіканні вагонів.

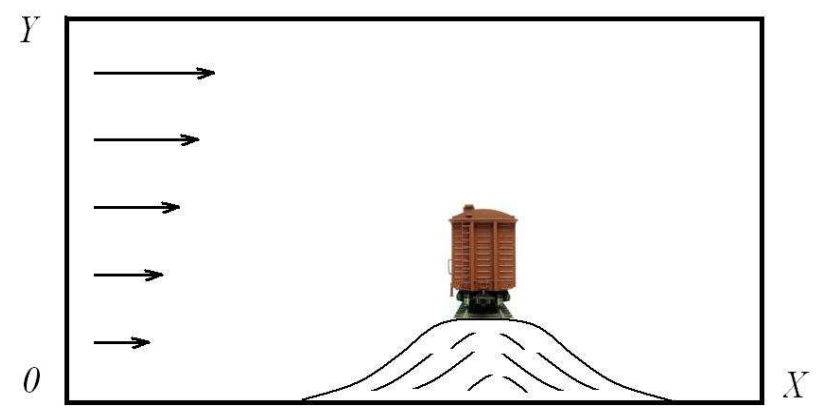

Рис. 1. Вагон на вершині сортувальної гірки

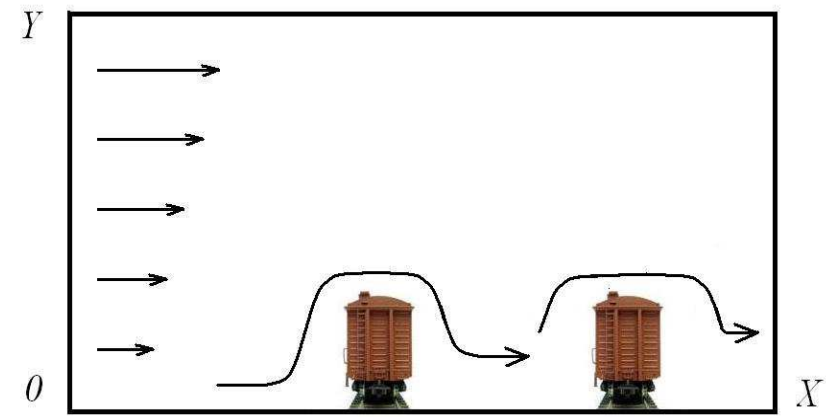

Рис. 2. Схема обтікання повітряним потоком вагонів у сортувальному парку

При побудові математичної моделі процесу обтікання повітряним потоком вагонів будемо враховувати усі перелічені вище фактори. Врахування рельєфу та форми вагонів при моделюванні ускладнює вирішення завдання, оскільки необхідно знайти розв'язок гідродинамічної задачі в області важкої геометричної форми.

Для розв'язання задачі визначення силового впливу повітряного середовища на відчепи (як на ті, що розташовані на коліях сортувального парку, так і на ті, що рухаються) з урахуванням нерівномірного поля 
швидкості повітряного потоку, яке було викликано обтіканням вагонів і рельєфу, необхідно використовувати модель потенціальної течії. Це пов'язано з тим, що при використанні моделей, що враховують в'язкість підстильної поверхні, необхідно застосовувати дуже дрібну розрахункову сітку і значні витрати комп'ютерного часу на отримання результату. Тому, виходячи з роботи М. Е. Берлянда [8], зробимо припущення, що повітряний потік - нестиснена рідина, а течія - потенціальна. В цьому випадку

$$
V=\operatorname{grad} P \text {, }
$$

де $P$ - потенціал швидкості.

Даний вираз можна записати у вигляді

$u=\frac{\partial P}{\partial x}, \quad v=\frac{\partial P}{\partial y}, \quad w=\frac{\partial P}{\partial z}$.

Якщо підставити ці вирази у рівняння нерозірваності, то отримуємо рівняння для визначення потенціалу швидкості (рівняння Лапласа) [9].

$\frac{\partial^{2} P}{\partial x^{2}}+\frac{\partial^{2} P}{\partial y^{2}}+\frac{\partial^{2} P}{\partial z^{2}}=0$

Необхідно зазначити, що розв'зання просторової гідродинамічної задачі $\epsilon$ достатньо важким, тому розглянемо просторову двовимірну модель, яка буде розраховувати компоненти вектора швидкості та враховувати нерівномірний профіль повітряного середовища. Рівняння гідродинамічної задачі при двовимірному випадку буде мати такий вигляд:

$\frac{\partial^{2} P}{\partial x^{2}}+\frac{\partial^{2} P}{\partial y^{2}}=0$

Зазначимо, що у цьому випадку вісь $Y$ буде направлена вертикально угору (профільна задача). Компоненти вектора швидкості повітряного потоку в цьому випадку визначається таким чином:

$u=\frac{\partial P}{\partial x}, \quad v=\frac{\partial P}{\partial y}$.

Як обгрунтування вибору моделі потенціальної течії для вирішення гідродинамічної задачі наведемо такі припущення:

- швидкість руху повітряного потоку значно менша за швидкість звуку;

- дана модель дає змогу розраховувати поле швидкості вітрового потоку при обтіканні вагонів та рельєфу місцевості за декілька секунд;
- вплив в'язкості буде виявлятись у вузькому шарі поблизу твердої поверхні.

Граничні умови для рівняння (4) такі [10]:

- на верхній та нижній межах розрахункової області на поверхні вагонів встановлюються умови непротікання:

$\frac{\partial P}{\partial n}=0$

де $n$ - одиничний вектор зовнішньої нормалі до границі, що розглядається;

- на межі «виходу» повітряного потоку 3 розрахункової області ставиться гранична умова виду $\mathrm{P}=$ const (умова Діріхле);

- на тих межах, де відбувається «втікання» повітряного потоку в розрахункову область, ставиться гранична умова виду

$\frac{\partial P}{\partial n}=V$

де $V$ - відома швидкість втікання (швидкість вітру).

У потоці, що набігає, відбувається розвиток внутрішнього примежового шару перед відчепами, що також необхідно враховувати при встановленні граничних умов. Вплив підстильної поверхні та відчепів на деякій відстані від них послаблюється, і швидкість руху у внутрішньому примежовому шарі безперервно переходить до швидкості потоку, що набігає.

У чисельній моделі, опис якої подано нижче, буде використовуватись нерівномірний профіль вітру на вході до розрахункової області [11]. У зв’язку з цим поздовжня складова швидкості вітру на вході в розрахункову область (див. рис. 1) задається залежністю

$u=u_{1}\left(\frac{y}{y_{1}}\right)^{n}$,

де $u_{l}$ - значення швидкості вітру на деякій фіксованій висоті у1;

$n$ - показник експоненти, який змінюється від 0 до 1 (приймаємо $n=0,15$ ) [12].

Для чисельного інтегрування рівняння (4) будемо використовувати ідею встановлення рішення за часом. У цьому випадку замість даного рівняння маємо рівняння еволюційного вигляду [13]:

$$
\frac{\partial P}{\partial t}=\frac{\partial^{2} P}{\partial x^{2}}+\frac{\partial^{2} P}{\partial y^{2}}
$$


де $t$ - фіктивний час.

Чисельне розв'язання даного рівняння визначається за допомогою змінно-трикутного методу О. А. Самарського [14]. Даний метод належить до групи методів розщеплення. На кожному кроці розщеплення різниці рівняння в цьому методі будуть записуватись так:

$$
\begin{gathered}
\frac{P_{i, j}^{n+1 / 2}-P_{i, j}^{n}}{0,5 \Delta \eta}=\frac{P_{i+1, j}^{n}-P_{i, j}^{n}}{\Delta x^{2}}+\frac{-P_{i, j}^{n+1 / 2}+P_{i-1, j}^{n+1 / 2}}{\Delta x^{2}}+ \\
+\frac{P_{i, j+1}^{n}-P_{i, j}^{n}}{\Delta y^{2}}+\frac{-P_{i, j}^{n+1 / 2}+P_{i, j-1}^{n+1 / 2}}{\Delta y^{2}}
\end{gathered}
$$

$$
\begin{gathered}
\frac{P_{i, j}^{n+1}-P_{i, j}^{n+1 / 2}}{0,5 \Delta \eta}=\frac{P_{i+1, j}^{n+1}-P_{i, j}^{n+1}}{\Delta x^{2}}+\frac{-P_{i, j}^{n+1 / 2}+P_{i-1, j}^{n+1 / 2}}{\Delta x^{2}} \\
+\frac{P_{i, j+1}^{n+1}-P_{i, j}^{n+1}}{\Delta y^{2}}+\frac{-P_{i, j}^{n+1 / 2}+P_{i, j-1}^{n+1 / 2}}{\Delta y^{2}} .
\end{gathered}
$$

Відмітною особливістю методу О. А. Самарського $\epsilon$ те, що він абсолютно стійкий, а розрахунок значення потенціалу швидкості $P_{i, j}$ на кожному кроці розчеплення відбувається за явною формулою методом біжучого розрахунку (рис. 3). Цей метод суттєво спрощує програмну реалізацію чисельної моделі.

Після розрахунку поля потенційної швидкості визначаються компоненти вектора швидкості вітру:

$u_{i j}=\frac{P_{i, j}-P_{i-1, j}}{\Delta x}$,

$v_{i j}=\frac{P_{i, j}-P_{i, j-1}}{\Delta y}$.

Оскільки чисельне інтегрування здійснюється для еволюційного рівняння, то для дискретної моделі задається початкова умова виду $P=P_{0}$ при $t=0$.

Розрахунок закінчується при виконанні умови вигляду

$\left|P_{i, j, k}^{n+1}-P_{i, j, k}^{n}\right| \leq \mathcal{E}$

де $\varepsilon$ - мале число;

$n$ - номер інтерації.

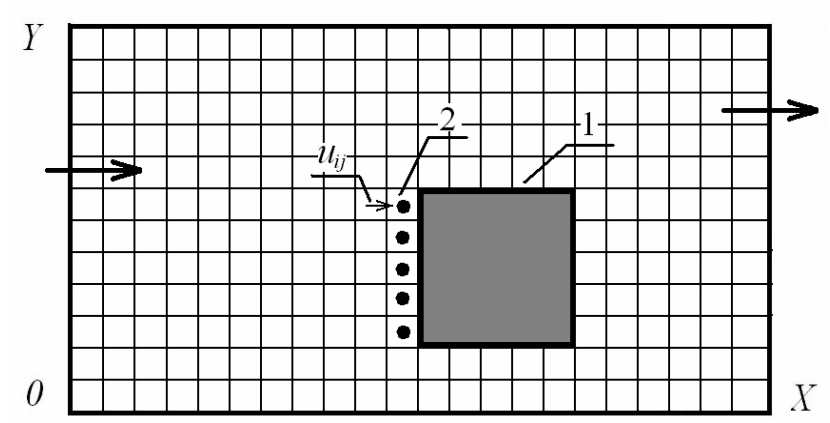

Рис. 3. Схема розрахункової сітки та контрольних вузлів

Після розрахунку поля швидкості вітрового потоку, у тому числі поблизу різницевих чарунок біля стінки вагона, розраховується повний тиск на елемент стінки вагона та відповідна сила:

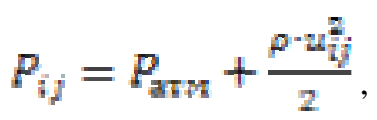

$F_{S_{i j}}=\sum P_{i j} S_{g}$,

де $P_{i j}$ - тиск у чарунці $i j, \mathrm{H} / \mathrm{M}^{2}$;

$\rho$ - щільність повітря, кг/ $\mathrm{M}^{3}$;

$F_{S_{i j}}$ - сила, що діє на елемент стінки вагона, H;

$S_{S}$ - площа елемента стінки вагона, м²;

$u_{i j}$ - локальна швидкість вітру біля елемента стінки вагона, м/с.

У моделі приймаються фіктивні різниці чарунки для реалізації умови непротікання на поверхні вагонів і землі.

\section{Висновки 3 даного дослідження і перспективи}

Побудована математична модель процесу обтікання повітряним потоком вагонів дає можливість визначення потенціалу швидкості на відчепи у будьякій точці сортувального парку, враховуючи профіль гірки, заповнення колій сортувального парку вагонами та різниці швидкості вітру у земному примежовому шарі з висотою для експрес-розрахунку.

У подальшому необхідно розвивати існуючу модель та будувати тривимірну модель.

\section{Література}

1. Zhau, W. Optimizing the long-term operating plan of railway marshaling for capacity utilization analysis [Text] / W. Zhau, X. Yang, J. Qin // The Scientific world journal. - 2014. - №3. - P. 71-84. 
2. Талалаев, В. И. Сопоставительный анализ технических средств для механизации и автоматизации сортировочных станций, применяемых на Российских железных дорогах и за рубежом [Текст] / В. И. Талалаев, А. Г. Савицкий. М.: ВНИИАС МПС России, 2007. - 150 с.

3. Огар, О. М. Аналіз роботи підсистем регулювання швидкості скочування відчепів в автоматизованих системах управління сортувальними станціями [Текст] / О. М. Огар, М. А. Асєєв, О. А. Іванченко // Зб. наук. праць Укр. держ. ун-ту залізнич. трансп. Харків: УкрДУЗТ, 2016. - Вип. 161. - С. 70-75.

4. Козаченко, Д. М. Исследование требований к системам прицельного регулирования скорости скатывания отцепов при автоматизации расформирования составов [Текст] / Д.М. Козаченко // Зб. наук. праць ДонІЗТ. - Донецьк: ДонІЗТ, 2010. № 22. - C. 5-13.

5. Козаченко, Д.Н. Исследование прицельного регулирования скорости скатывания отцепов в условиях неопределенной информации об их ходовых свойствах [Текст] / Д.Н. Козаченко, Р.Г. Коробьева, О.И. Таранец // ВосточноЕвропейский журнал передовых технологий. - 2009. - № 6/3 (42). - С. 42-47.

6. Асєєв, М. А. Розробка напрямку щодо підвищення точності розрахунку швидкості виходу відчепів 3 паркової гальмової позиції [Текст] / М. А. Асєєв // 3б. наук. праць Дніпропетровського національного університету залізничного транспорту ім. академіка В. Лазаряна. - Дніпропетровськ: ДНУЗТ, 2016. № 12. - С. 5-9.

7. Берлянд, М. Е. Современные проблемы атмосферной диффузии и загрязнения атмосферы [Текст] / М. Е. Берлянд. - Л.: Гидрометеоиздат, 1975. - 448 с.

8. Берлянд, М.Е. Прогноз и регулирование загрязнения атмосферы [Текст] / M.Е. Берлянд - Л.: Гидрометеоиздат. - 1985. - 273 с.

9. Лойцянский, Л. Г. Механика жидкости и газа [Текст] / Л. Г. Лойцянский. - M.: Государственное издательство технико-теоретической литературы, 1950. - $678 \mathrm{c}$.

10. Роуч, П. Вычислительная гидродинамика [Текст] / П. Роуч. - М.: Мир, 1980. - 616 с.

11. Уорк, К. Загрязнение воздуха. Источники и контроль [Текст] / К. Уорк, С. Уорнер. - М.: Мир, 1980. - 539 с.

12. Hanna, S. Air Quality Modelling over. Short Distances. [Text] / S. Hanna // College on atmospheric boundary layer and air pollution modeling. - 1994. -NSMR/7602. P 712-743.

13. Згуровский, M. 3. Численное моделирование распространения загрязнения в окружающей среде [Текст] / М. 3. Згуровский, В.В. Скопецкий, В. К. Хрущ, Н. Н. Беляев. - К.: Наукова думка, 1997. -368 c.

14. Самарский, А. А. Теория разностных схем [Текст] / А. А. Самарский. - М.: Наука, 1983. - 616 с.
Асеев М. А. Разработка математической модели процесса обтекания вагонов воздушным потоком. Проанализирована работа подсистем автоматического регулирования скорости скатывания отцепов в автоматизированных системах управления сортировочными станциями. Сформирован научный подход об определении потенциала скорости ветра при обтекании вагонов для повышения точности расчета скорости выхода отцепов с парковой тормозной позиции. Предложенный подход позволяет учитывать переменное значение скорости ветра, деформацию поля скорости ветра при обтекании рельефа и вагонов на путях сортировочного парка.

Ключевые слова: сортировочная горка, деформация поля скорости ветра, метеорологические параметры, потенциал скорости, отцеп.

Asieiev M. A. Development of mathematical model of process of flowing around of carriages the current of air. The analysis of work of different subsystems of automatic control of speed of rolling wagons is conducted in automated control system by marshaling yards. New scientific approach is formed about determination of potential of speed of wind at flowing around of carriages for the increase of exactness calculation of speed exit wagons from park brake position. Calculates the rate of exit from the park brake position suggested taking into account the revised rates of meteorological conditions. The mathematical model allows us to calculate the value of the potential speed at any point of the park based on the variable value of the wind speed at height, difficult terrain hump, wagons influence are on the ways of sorting the park, the deformation field of wind speed in the flow of terrain sorting park, deformation field wind speed flow of cars on the tracks screening park. Worked out method maybe in future to use for calculation of speed of exit of wagons in from park brake position.

Keywords: sorting hill, deformation of the field speed of wind, meteorological parameters, potential of speed, wagon.

Надійшла 27.02.2017p.

Асєєв М. А., провідний інженер планово-виробничого відділу, Харківське відділення філії «Проектновишукувальний інститут залізничного транспорту» ПАТ «Укрзалізниия», Харків, Україна. E-mail: aseev.maksim1988@gmail.com

Asyeyev M. A., leading engineer, Kharkiv branch office "Project and survey institute of railway transport»PJS «Ukrainian railway», Kharkiv, Ukraine. E-mail: aseev.maksim1988@gmail.com 